\title{
Liquid-water content and water distribution of wet snow using electrical monitoring.
}

\author{
Pirmin Philipp Ebner ${ }^{1}$, Aaron Coulin ${ }^{1}$, Joël Borner ${ }^{1}$, Fabian Wolfsperger ${ }^{1}$, Michael Hohl ${ }^{1}$, \\ Martin Schneebeli ${ }^{1}$ \\ ${ }^{1}$ WSL Institute for Snow and Avalanche Research SLF, Davos Dorf, 7260, Switzerland \\ Correspondence to: Martin Schneebeli (schneebeli@slf.ch)
}

\section{Abstract:}

Snow exists in a wide range of temperatures and around its melting point snow becomes a three-phase material. A better understanding of wet snow and the first starting point of water percolation in the seasonal snowpack is essential for snow pack stability, snow melt run-off and remote sensing. In order to induce and measure precisely the liquid water and the corresponding dielectric properties inside a snow sample, an experimental setup was developed. Using microwave heating at $18 \mathrm{kHz}$ allows the use of dielectric properties of ice to enable heat to be dissipated homogeneously through the entire volume of snow. A desired liquid water content inside the snow sample could then be created and analysed in a micro-computer tomography. Based on the electrical monitoring a promising perspective for retrieving water content and water distribution in the snowpack is given. The heating process and extraction of water content are mainly dependent on the morphological properties of snow, the temperature and the liquid water content. The experimental observation can be divided in three different heating processes affecting the dielectric properties of snow for different densities: (1) dry snow heating process up to $0{ }^{\circ} \mathrm{C}$ indicating a temperature and snow structure dependency of the dielectric property of snow; (2) wet snow heating at stagnating temperature of $0^{\circ} \mathrm{C}$ and the presence of uniformed distributed liquid water changes the dielectric properties. The presence of liquid water decreases the impedance of the snow sample until water starts to percolate; and (3) the start of water percolation is between 5-12 water volume fraction depending on the 
https://doi.org/10.5194/tc-2020-56

Preprint. Discussion started: 3 May 2020

(C) Author(s) 2020. CC BY 4.0 License.

31 snow density and confirms the literature findings. The onset of water percolation

32 initiated an inhomogeneity in snow and water distribution, strongly affecting the

33 dielectric properties of the snow. These findings are pertinent to the interpretation of

34 the snow melt run-off of spring snow. These laboratory measurements allow to find

35 the narrow range of the starting point of water percolation in coarse-grained snow and

36 to extract the corresponding dielectric properties which is important for remote

37 sensing. 


\section{Introduction}

39 Snow, a sintered porous material made of ice grains, has a complex porous microstructure and consist of a continuous ice structure at temperature below zero degrees (Löwe et al., 2011). Reaching the melting point, snow becomes a threecomponent mixture of ice, water and air. A detailed understanding of the influence of liquid water on the snow microstructure is essential. It influences radar and microwave attenuation, sub-surface exploration, remote sensing, radar altimetry, electrical grounding, atmospheric electrical fields and electrostatic charging by precipitation and blown particles (Mellor, 1977). Liquid water in snow is also a critical factor for estimating the hazard of wet snow avalanches and the transmission of melt-water through a snow-pack (Evans, 1965; Reiweger et al., 2015).

49 Estimating liquid water content is difficult even for experienced observers (Martinec, 1991; Fierz and Föhn, 1994), partly because water flow through snow varies both spatially and temporally (e.g. Colbeck 1979; Marsh, 1988; Conway and Benedict, 1994). Introduction of liquid water into snow changes morphological (Brun, 1989; Coléou and Lesaffre, 1998; Raymond and Tusima, 1979; Brun, 1989; Marsh, 1987;

54 Colbeck, 1997; Marshall et al., 1999; Jordan et al., 2008) and mechanical properties

55 of snow (Techel et al., 2011; Colbeck, 1982). When liquid water occurs for the first

56 time in the seasonal snowpack, much water can be hold as small grains cause high capillary forces. After a couple of melt-freeze cycles smaller grains disappear and less melt-water is held immobile in the snow matrix (Yamaguchi et al., 2010). This delays water runoff during the early stages of snowpack melt-out and snow can retain liquid water (Colbeck, 1972; Linsley et al, 1949). Reaching a saturation point, the liquid water is then released suddenly. The transition point where the liquid water starts to

62 percolate in the snow sample is important because it dominates the spring runoff period in many regions.

Measuring the liquid water content non-destructively and homogeneously in larger snow samples (in centimetre regime) is very challenging. The small amount of liquid water present and the sensitivity of the snow to the various processes to induce a defined liquid water content makes the measurements hard. Radiative absorption or

68 snow melting in a room at $0^{\circ} \mathrm{C}$ induces a temperature gradient from the surface to the core of the snow sample leading to an inhomogeneous liquid-water content 
distribution. The direct supply of liquid water causes percolation in preferential selected channels. In both cases, the water distribution is not homogeneous and the exact extraction of the starting point of water percolation is not possible. In contrast,

73 Coléou and Lesaffre (1998) performed experiments by slowly saturate a snow sample

74 fully with water and afterwards drained out to find the starting point of water

75 percolation. They approached the water retention curve of snow (Yamaguchi et al., 2010) from the right site. In these experiments water percolation was initiated at

77 around 5-14 \% of mass volume for snow density between $350 \mathrm{~kg} \mathrm{~m}^{-3}$ and $680 \mathrm{~kg} \mathrm{~m}^{-3}$

78 (Coléou and Lesaffre, 1998).

79 Another way to induce a homogeneous liquid-water content into the snow without 80 destroying the snow sample is microwave heating (Brun, 1989; Camp and LaBrecque, 1992). In this case, the water retention curve of snow (Yamaguchi et al., 2010) is approached from the left site. A uniform electric field oscillating at an appropriate frequency excites the dielectric properties of ice enabling heat to be dissipated through the whole volume of snow (Mellor, 1977; Brun, 1989; Camp and LaBrecque, 1992). The dielectric properties of the ice depend on the frequency, temperature and snow density. The applied field results in a displacement of charged particles in the insulating material, giving rise to induced dipoles. The permanent dipoles of the water molecule respond to the electric field, which results in a temperature increase of the material. The heat absorption by the ice phase is uniform and the absorbed energy depends only on the imaginary part $\varepsilon^{\prime \prime}$ of permittivity (Polder and Van Santen, 1946).

Dielectric properties of dry snow are closely related to solid ice. The ideal relaxationfrequency of ice is at $7.5 \mathrm{kHz}$ (Auty and Cole, 1952). However, the relaxation frequency of dry snow lies between 10 and $100 \mathrm{kHz}$ depending on the snow density and temperature (Bader and Kuroiwa, 1962; Polder and Van Santen, 1946; Evans, 1965). The presence of liquid water strongly affects the dielectric properties of the wet snow sample (Sweeny and Colbeck, 1974; Ambach and Denoth, 1980, Camp and LaBrecque, 1992). A wide spectrum of frequencies has been explored to determine the free water content of water in snow (Ambach and Denoth, 1975; Boyne and Fisk, 1987; Brun, 1989; Denoth et al., 1984; Denoth and Foglar, 1986; Perla, 1990; Camp and LaBrecque, 1992). As long as the liquid water phase remains discontinuous on the ice matrix (Brun E., 1989), the dielectric properties of the wet snow sample are 
homogenous over the whole sample and the amount of liquid water can be estimated

103

104 (Ambach and Denoth, 1972, Koch et al., 2014). At the point where the liquid water starts to percolate, an inhomogeneous distribution of water and ice starts to build up in the total snow sample and locally affects the dielectric properties of the sample. Work by Camp and LaBrecque (1992) showed that dielectric heating at $20 \mathrm{kHz}$ is a useful means of modifying the water content from 0 to $30 \%$ by weight.

The objective of this paper is to present an experimental setup to allow standardized studies to extract the starting point of water percolation depending on snow density and dielectric properties. We developed a dielectric heating device at $18 \mathrm{kHz}$, similar to the work by Brun (1989) and Camp and LaBrecque (1992), to find the narrow range of the starting point of water percolation in coarse-grained snow. We improved the suggested power measurements by improving the measurement of phase to be more sensitive in the control of water content. Our technique of monitoring the voltage, current and phase shift at the two copper plates makes it possible to study the dielectric properties of the snow as the water content changes. In particular, at temperature close to the melting point the surface properties of the ice change markedly affecting the dielectric properties. Additionally, with the well-controlled electrical heating the exact water content of water percolation of different kind of snow densities and surface-to-volume ratio can be extracted. We analysed three regimes: (1) dry snow heating showing the fraction of energy absorption of the snow, (2) producing wet snow to investigate the starting point of water percolation based on the electrical properties and density of the snow. Additionally, primarily quantifying of the water content in three-dimensional space without destroying the snow structure are analyzed using micro computed tomography (micro-CT); (3) water percolation affecting the overall impedance of the snow sample.

\section{Experimental setup}

The experimental setup is shown schematically in Fig. 1 and a photo of the experimental setup is shown in Fig. 2. The device consists of three functional blocks: (1) low voltage circuit to generate the sinusoidal signal and amplify the energy output, (2) high voltage circuit to transform the low primary voltage to a high secondary voltage, and (3) design of the sample holder between the high voltage capacitor plates. 
133 The core of the snow heater is a Red Pitaya STEM 125-14 using for signal generation 134 and data acquisition, and is controlled via Standard Commands Programmable 135 Instruments SCPI in Matlab. The low voltage sinusoidal input signal with a frequency 136 of $18 \mathrm{kHz}$ is generated by a high-speed digital to analog converter and is amplified 137 afterwards to stabilizes the electrical potential in the circuit. A step-up transformer 138 transforms the low primary voltage to a high secondary voltage of around $350 \mathrm{~V}$ 139 applied to two copper plates inducing the dielectric heat into the snow sample. The 140 surface of the copper plates is electrically insulated to prevent Joule heating of the 141 snow sample. The snow sample was placed into a polyoxymethylene (POM) ring 142 (diameter $=60 \mathrm{~mm}$, distance $=13 \mathrm{~mm}$ ) and inserted between the two capacitor plates.

143 The snow sample and the capacitor are thermally insulated with extruded polystyrene

144 foam (XPS) with a thickness of $120 \mathrm{~mm}$ to prevent radial conductive and convective 145 heat losses.

146 The applied sinusoidal waveforms of voltage $U(\mathrm{t})$ to the copper-plates is attached to a 147 differential probe and is measured galvanic sorted with a 100 -fold attenuation. The 148 current $I(\mathrm{t})$ from the plate is measured via a shunt resistor. The phase shift $\varphi(t)$ 149 between the sinusoidal waveforms of voltage and current is measured between the 150 circuit's input and circuit's output signal. An input protection circuit prevent the analog 151 to digital converter from damage in case of a short circuit. The voltage connection 152 between the low and high voltage part is measured via a shunt resistor. This 153 connection defines the star point of the circuit and makes sure that the second part of 154 the circuit doesn't thrift away. It is the only star point preventing the circuit from circular 155 currents. A negative temperature coefficient element is placed one centimetre inside 156 the snow sample to measure the temperature. A low pass filter is applied to block the 157 noise of the capacitor.

158 The total power $P_{\mathrm{RMS}}(\mathrm{t})$ between the two copper-plates is calculated based on the root159 mean-squared voltage $U_{\text {RMS }}(t)$, current $I_{\text {RMS }}(t)$ and the measured phase difference $\varphi(t)$

$$
P_{\mathrm{RMS}}(t)=U_{\mathrm{RMS}}(t) \cdot I_{\mathrm{RMS}}(t) \cdot \cos \varphi(t)
$$

161 The impedance $R_{\mathrm{RMS}}(\mathrm{t})$, describing the resistant of the snow sample, between the two 162 copper-plates is given by 


$$
R_{R M S}(t)=\frac{U_{\mathrm{RMS}}(t)}{I_{\mathrm{RMS}}(t)}
$$

164 The uncertainties of the temperature $T(\mathrm{t})$, current $I_{\mathrm{RMS}}(\mathrm{t})$, voltage $U_{\mathrm{RMS}}(\mathrm{t})$, phase shift $165 \varphi(t)$, total power consumed $P(\mathrm{t})$, and density of the snow measured by weighting are:

$166 \pm 0.05^{\circ} \mathrm{C}, \pm 0.01 \mathrm{~mA}, \pm 0.5 \mathrm{~V}, \pm 2$ degrees, $\pm 0.005 \mathrm{~W}$ and $\pm 20 \mathrm{~kg} \mathrm{~m}^{-3}$.

\section{$167 \quad 2.1$ Tomography experiments}

168 A cooled micro-computer tomograph (CT; Scanco Medical $\mu$-CT80) at a cold 169 laboratory temperature of $-5^{\circ} \mathrm{C}$ was used to visually quantify the water content in 170 three-dimensional space without destroying the snow structure. The scanned image 171 had a volume of $200 \times 200 \times 20$ voxels $(3.6 \mathrm{~mm} \times 3.6 \mathrm{~mm} \times 0.36 \mathrm{~mm})$ with a nominal

172 voxel resolution of $18 \mu \mathrm{m}$. The grey scale resolution for each voxel was 16 bit and a 173 Gaussian filter $(\sigma=1.4$, support $=3$ ) was applied to reconstruct the micro-CT images.

174 The volume was segmented to a binary image by classifying each voxel by ice or air.

175 The threshold for the segmentation process was chosen such as that the manually 176 measured density did not deviate more than $12 \%$ from the CT-density in the 177 segmentation process (Riche and Schneebeli, 2013). Each scan took around $2.7 \mathrm{~h}$.

178 Absorption by water and ice are almost identical (Lieb-Lappen et al., 2017), and are

179 hardly to separate in the segmentation process. Therefore, the water creation on the 180 snow surface was extracted by superposition of two micro-CT scans. One scan was 181 taken before the heating process and the second one afterwards. Before the second micro-CT scan, the wet snow sample was shock frozen at $-30{ }^{\circ} \mathrm{C}$ to preserve the snow structure. This allowed us to easily visualize and to extract the water creation on the surface of the ice matrix with an uncertainty of $4 \%$.

\section{Method}

The phenomena involved in microwave heating of snow are volumetrically absorption of electromagnetic energy to achieve self-heating uniformly and rapidly, which is characterized by the density of the snow. The dielectric power absorption $P$ is equal to the total power consumed $P_{\mathrm{RMS}}$, given by:

$$
P=2 \cdot \pi \cdot f \cdot E^{2} \varepsilon_{0} \cdot \varepsilon_{\mathrm{s}}^{\prime \prime}\left(f, \rho_{\mathrm{s}}, T_{\mathrm{s}}\right) \cdot A \cdot d=P_{\mathrm{RMS}}
$$


191 where $f$ is the frequency, $E=U d^{-1}$ the electric field, $\varepsilon_{0}=8.85 \cdot 10^{-12}$ the electric field

192 constant, $\varepsilon_{\mathrm{s}}^{\prime \prime}$ the imaginary part of the complex dielectric constant of snow, $A$ the 193 capacitors surface area and $d$ the distance between the two copper-plates.

194 Rearranging Eq. (3) the imaginary part of the complex dielectric constant of dry snow 195 is given by

$$
\varepsilon_{\mathrm{s}}^{\prime \prime}\left(f, \rho_{\mathrm{s}}, T_{\mathrm{s}}\right)=\frac{P_{\mathrm{RMS}}}{2 \cdot \pi \cdot f \cdot E^{2} \cdot \varepsilon_{0} \cdot A \cdot d}
$$

which depends on the frequency $f$, snow density $\rho_{\mathrm{s}}$, and snow temperature $T_{\mathrm{s}}$.

198 The heating efficiency is an important factor to evaluate the heating process. It is 199 defined as the ratio of energy absorbed by the heated sample to that radiated from the 200 microwave source [Ali, 2016] given by:

$$
\eta=\frac{Q_{\text {setup }}-Q_{\text {sample }}}{Q_{\text {setup }}}=1-\frac{m_{\mathrm{s}} c_{\mathrm{p}}\left(T_{1}-T_{0}\right)}{\int_{0}^{t_{1}} P_{\mathrm{RMS}}(t) d t}
$$

202 where $m_{\mathrm{s}}$ is the mass of the snow sample, $c_{\mathrm{p}}$ the specific heat capacity, $T_{0}$ and $T_{1}$ the

203 initial temperature and melting temperature at $0{ }^{\circ} \mathrm{C}$, and $t_{1}$ the time until temperature 204 reached $0{ }^{\circ} \mathrm{C}$.

205 The liquid water mass fraction for each timestep $t$, is calculated by the fraction of the measured dissipated latent heat and total latent heat needed for the phase change:

$$
x_{\text {mass }}(t)=\frac{\int_{t_{1}}^{t} \eta \cdot P_{\mathrm{RMS}}(t) d t}{h_{\text {latent }} m_{\mathrm{S}}}
$$

208 where $h_{\text {latent }}=334 \mathrm{~kJ} \mathrm{~kg}^{-1}$ is the latent heat for the phase change from ice to water and

$209 t_{1}$ the time step where the snow sample reached $0{ }^{\circ} \mathrm{C}$.

210 The liquid water volume fraction is given by [Coléou and Lesaffre, 1998]:

$$
x_{\mathrm{vol}}(t)=\frac{x_{\mathrm{mass}} \cdot \rho_{\mathrm{s}}}{\rho_{\mathrm{i}}-\rho_{\mathrm{s}}} \cdot \frac{\rho_{\mathrm{i}} / \rho_{\mathrm{w}}}{1-x_{\text {mass }}}
$$


212 where $\rho_{\mathrm{s}}, \rho_{\mathrm{i}}$ and $\rho_{\mathrm{w}}$ are the snow, ice $\left(917 \mathrm{~kg} \mathrm{~m}^{-3}\right)$ and water $\left(999.9 \mathrm{~kg} \mathrm{~m}^{-3}\right)$ density.

213 The uncertainties of $x_{\text {mass }}$ and $x_{\text {vol }}$ are $10 \%$ due to the uncertainty of the power $( \pm 0.005$

$214 \mathrm{~W})$ and density measurement $\left( \pm 20 \mathrm{~kg} \mathrm{~m}^{-3}\right)$.

\section{4. Results}

216 Deionized water with a conductivity of $\approx 0.2 \mu \mathrm{S} \mathrm{cm}^{-1}$ was used to produce natural 217 identical snow (Schleef et al., 2014) in a cold laboratory at $-20^{\circ} \mathrm{C}$. The produced snow 218 was sieved into sample holders (mesh size: $2 \times 2 \mathrm{~mm}$ ) and was sintered at a temperature of $-2{ }^{\circ} \mathrm{C}$ for two to five days to allow the snow crystals to form a uniform grain size. A hydraulic press compressed the snow to densities between 400 and 600 $\mathrm{kg} \mathrm{m}^{-3}$ to represent snow packs in spring (Bartelt and Lehning, 2002). We analysed in total seven different snow samples.

The measured electrical properties between the two copper-plates were strongly influenced by the temperature, water content, and density of the snow sample. The higher the snow density and the water content in the snow was, the stronger the measured electrical properties were affected, shown in Table 1. Figure 3 shows a

227 typical measured temperature $T(\mathrm{t})$, current $I_{\text {RMS }}(\mathrm{t})$, voltage $U_{\mathrm{RMS}}(\mathrm{t})$, and phase shift $\varphi(\mathrm{t})$

228 profile of a heating process for snow density of (a) $438 \mathrm{~kg} \mathrm{~m}^{-3}$, (b) $539 \mathrm{~kg} \mathrm{~m}^{-3}$, (c) 612 $\mathrm{kg} \mathrm{m}^{-3}$, and (d) $917 \mathrm{~kg} \mathrm{~m}^{-3}$. The temperature profile shows the characteristic of the snow heating process increasing from $-1^{\circ} \mathrm{C}$ up to $0{ }^{\circ} \mathrm{C}$. Afterwards the temperature stagnates at $0{ }^{\circ} \mathrm{C}$ and the supplied energy was used for the phase change from ice to liquid water. The current profile has a different behaviour. It shows a slightly linear increase until the snow sample reached a temperature of $0^{\circ} \mathrm{C}$. Afterwards the incline

234 of the current curve further increased reaching the highest current of $1.7 \mathrm{~mA}, 2.6 \mathrm{~mA}$, $2353.8 \mathrm{~mA}$, and $4.3 \mathrm{~mA}$ at around $80 \mathrm{~min}, 60 \mathrm{~min}, 55 \mathrm{~min}$, and $9 \mathrm{~min}$ for snow with densities of $438 \mathrm{~kg} \mathrm{~m}^{-3}, 539 \mathrm{~kg} \mathrm{~m}^{-3}, 612 \mathrm{~kg} \mathrm{~m}^{-3}$, and $917 \mathrm{~kg} \mathrm{~m}^{-3}$. After this maximum

237 the current started to decrease with time. The voltage and phase shift showed a mirror 238 inverted behaviour to the current profile. Both parameters decreased with time and 239 increased afterwards again. At the beginning a phase shift of $55.9^{\circ}, 52.8^{\circ}, 50^{\circ}$, and $46.9^{\circ}$ were measured with the lowest phase shift of $41.3^{\circ}, 35.2^{\circ}, 31.5^{\circ}$, and $22.4^{\circ}$ for snow densities of $438 \mathrm{~kg} \mathrm{~m}^{-3}, 539 \mathrm{~kg} \mathrm{~m}^{-3}, 612 \mathrm{~kg} \mathrm{~m}^{-3}$, and $917 \mathrm{~kg} \mathrm{~m}^{-3}$. 
242 The snow temperature, density and water content strongly affected the impedance

243 and the total power consumed by the snow sample. The impedance decreased with increasing temperature, water content, and density, vice versa for the total power consumed, shown in Table 2. Figure 4 shows a typical calculated total power $P_{\text {RMS }}(t)$ and impedance $R_{\mathrm{RMS}}(\mathrm{t})$ profile compared with the measured temperature profile of a heating process for snow density of (a) $438 \mathrm{~kg} \mathrm{~m}^{-3}$, (b) $539 \mathrm{~kg} \mathrm{~m}^{-3}$, (c) $612 \mathrm{~kg} \mathrm{~m}^{-3}$, and (d) $917 \mathrm{~kg} \mathrm{~m}^{-3}$. The impedance had the same profile behaviour like the phase shift starting with $368.4 \mathrm{k} \Omega, 275.5 \mathrm{k} \Omega, 213.5 \mathrm{k} \Omega$, and $123.1 \mathrm{k} \Omega$ reaching a minimum of $197.4 \mathrm{k} \Omega, 127.3 \mathrm{k} \Omega, 87.3 \mathrm{k} \Omega$, and $73.5 \mathrm{k} \Omega$ after $80 \mathrm{~min}, 60 \mathrm{~min}, 55 \mathrm{~min}$, and $9 \mathrm{~min}$ for snow density of $438 \mathrm{~kg} \mathrm{~m}^{-3}, 539 \mathrm{~kg} \mathrm{~m}^{-3}, 612 \mathrm{~kg} \mathrm{~m}^{-3}$, and $917 \mathrm{~kg} \mathrm{~m}^{-3}$. The total power consumption profile was mirror inverted. It started with $0.17 \mathrm{~W}, 0.25 \mathrm{~W}, 0.33 \mathrm{~W}$, and $0.63 \mathrm{~W}$ and reached a maximum of $0.41 \mathrm{~W}, 0.69 \mathrm{~W}, 1.04 \mathrm{~W}$, and $1.24 \mathrm{~W}$ after $80 \mathrm{~min}$, $60 \mathrm{~min}, 55 \mathrm{~min}$, and $9 \mathrm{~min}$ for snow density of $438 \mathrm{~kg} \mathrm{~m}^{-3}, 539 \mathrm{~kg} \mathrm{~m}^{-3}, 612 \mathrm{~kg} \mathrm{~m}^{-3}$, and $917 \mathrm{~kg} \mathrm{~m}^{-3}$.

The heating efficiency was affected by heat loss at the wall and decreases with higher snow density. The microwave power did not directly penetrate into the snow samples but also through the air space of the pores. As a result, the reflection of microwave power on the interface, which was caused by the relative permittivity mismatch between the air and the sample led to limited heating efficiency. As the frequency of $18 \mathrm{kHz}$ was in the range of the optimal snow heating frequency between 10 and 100 $\mathrm{kHz}$ depending on the snow density (Bader and Kuroiwa, 1962; Polder and Van Santen, 1946; Evans, 1965), the efficiency of the heating samples was usually higher for lower density. This effect is confirmed by Fig. 5 showing the heating efficiency and the complex dielectric constant of dry snow at $T=0^{\circ} \mathrm{C}$ for various snow sample. The error bars indicate the measured uncertainty of the experimental setup. Ice had the lowest heating efficiency with the highest extracted permittivity value of $\varepsilon_{i}^{\prime \prime}=30.65$, similar to literature values of $\varepsilon_{\mathrm{i}}^{\prime \prime}=30.93$ at $18 \mathrm{kHz}$ [Fujita et al., 2000].

\section{The start of water percolation was between 5-12 water volume fraction depending on} the snow density. Dense snow absorbed more microwave energy leading to higher liquid water content in a snow sample in a short time. The temporal evolution of the liquid water mass and volume fraction based on the measured power for the different snow samples (Fig. 6) increased with time and the influence of snow density was 
274 observed. At the maximum of consumed power $P_{\mathrm{RMS}}(\mathrm{t})$ a water mass and volume

275 fraction of 7.1 and $6.1,6.7$ and 8.8, 8.7 and 15.4, and 0.4 and 0 for snow density of

276 (a) $438 \mathrm{~kg} \mathrm{~m}^{-3}$, (b) $539 \mathrm{~kg} \mathrm{~m}^{-3}$, (c) $612 \mathrm{~kg} \mathrm{~m}^{-3}$, and (d) $917 \mathrm{~kg} \mathrm{~m}^{-3}$ was reached. Table

2773 shows the estimated water mass and volume fraction and time of the different snow

278 sample at the reversal point of the measured power, indicating the start of water

279 percolation.

280 The created water led to a stronger rounding of the ice crystals and the effect of fast

281 wet snow metamorphism was observed where a growth in size of snow crystals was

282 identified (Colbeck and Davidson, 1973). Figure 7 shows preferential spots of water

283 accumulation inside the snow structure. Blue indicates the ice structure and orange

284 shows the water part. The snow sample with an initial density of around $682 \mathrm{~kg} \mathrm{~m}^{-3}$

285 was heated to induce a volume water content of $16 \%$. A volume water content of

286 around $13.3 \%$ was extracted from the difference in the micro-CT scans before and

287 after the experiments. This rounding effect is also shown in an insight in the snow

288 heating process by a microscopy image illustrated in Fig. 8. The photography on the

289 left shows a snow structure of dry snow before and on the right after the experimental

290 run.

\section{4. Discussion}

292 Our major experimental results are summarized in Fig. 4 and 6, and in Table 2 and 3.

293 The dominant sources of absolute errors in the measurement of the water mass and

294 volume fraction in the snow were the snow density and the inaccuracy in the power

295 measurement. Especially, at snow densities below $450 \mathrm{~kg} \mathrm{~m}^{-3}$ this might cause

296 deviations of $\pm 1 \%$ in the water mass and volume fraction measurement. However, at

297 higher snow densities the relative errors were considerably less.

298 The snow structure and the water content had a major impact on the electrical 299 properties showing the same behaviour like in the work of Camp and LeBraque (1992).

300 In both works the electrical power increased with increasing water content and drops

301 at one point again. Based on the findings we divided the heating process in three

302 areas, shown in Fig. 9: 
303 (1) Dry snow: The heating process up to $0{ }^{\circ} \mathrm{C}$ indicated a temperature and snow structure dependency on the measured values. As snow temperature reached the melting point, the surface properties of the ice structure changed markedly and affected the electrical properties. The vibration and the mobility of protons enhanced and influenced the electrical conductivity leading to a decrease of the impedance. Further, at higher density the structural connections between ice crystals were less destructed by the pore volumes. This allowed a higher rate of flow of electric charge leading to a higher electric current. Additionally, the electrical potential between the two copper-plates was less affected by the pore volume leading to a more stable voltage and smaller phase shift between voltage and current. As a result, the electrical conductivity increased resulting in a lower impedance and a higher electrical energy transfer.

(2) Wet snow: Snow was becoming a particularly complicated medium because the introduction of liquid water caused rapid changes of the important material properties. The temperature stagnated at $0^{\circ} \mathrm{C}$ and the presence of uniformed distributed liquid water changed the dielectric properties of the snow sample. Additionally, the liquid water layer at the surface allowed the mobility of protons resulting in stronger rate of flow of electric charge and therefore enhanced the electrical conductivity. This reduced the impedance of the two-phase material significantly leading to a decrease of the impedance and phase shift, and an increase in electric current and power.

(3) Water percolation: The water started to percolate and liquid water accumulated at the bottom of the sample holder. The missing water in the upper part of the sample holder treasured up at the bottom of the sample holder and left empty spots at the top where the density decreased locally. The snow probe was not homogeneous anymore leading to a decrease in the electrical conductivity. As a result, the impedance increased again and the electric power decreased. First camera picture of water percolation after an experimental run is shown in Fig. 10. The sample holder was aligned vertically between the capacitor plates. Water percolated in the upper part of the sample and accumulated at the bottom of the sample holder leading to an inhomogeneous mixture of the sample. This inhomogeneous mixture changed the dielectric properties of the complete sample and affected the heating process. After 
this state the relative error of the water mass and volume fraction calculation

335 increased.

336 Based on the findings, water percolation occurred over a narrow range of values in

337 coarse-grained snow (see Table 3 ) and was initiated at around 5-8 \% of the mass

338 volume (see Table 3). For high snow densities where the surface-to-volume ratios were small, our results were lower than found by Coléou and Lesaffre (1998).

340 Following reasons are: (1) they approached the retention curve of snow (Yamaguchi

341 et al., 2010) from the opposite site and therefore the physical processes were different,

342 (2) they fully saturated the snow sample for about 5 minutes. Therefore, the surface tension of water had an additional effect, like a suction effect, holding more water in

344 the pore space. In our approach water could not be held immobile as the percolation

345 started earlier at the smooth ice surface.

346 Although the micro-CT measurements (see Fig. 7) showed a snow sample after the

347 water percolation point, still preferential spots of water accumulation inside the snow

348 structure could be seen. Three interesting observations were visible after percolation:

349 (1) No water film around the snow structure but isolated smaller and larger water

350 accumulations were visible indicating that phase change from ice to water were

351 happening on preferential spots on the ice crystal. However, it has to mention that the

352 pixel resolution was too coarse to detect an additional thin water film around the snow

353 structure. The created water led to a stronger rounding of the ice crystals and the

354 dendritic structure further disappeared. Nevertheless, no big change in grain shape

355 was observable due to the high density. (2) The gravity had no influence on the 356 orientation of the accumulated water on the ice crystal. It is apparent that the water 357 was uniformly distributed on the single ice crystals. The water droplets were too small 358 to be distracted by the gravity. (3) Single water accumulation links between single 359 neighbouring ice crystals can be seen. The refreezing of the snow sample after the 360 experiment led to single crystals agglomeration and a growth in size of snow crystals 361 (Colbeck and Davidson, 1973).

362 The electrical heating procedure developed to incrementally melt snow in order to vary 363 the water content and to analyse the created water non-destructive in a micro-CT 364 worked very well. Improving the experimental setup that the frequency can be 365 increased to the $\mathrm{GHz}-\mathrm{MHz}$ regime for a short period of time, the exact dielectric snow 
property based on the snow morphology and water content can be extracted. This will allow to improve remote sensing and field measurements on the snow-waterequivalent (Ambach and Denoth, 1972, Koch et al., 2014).

\section{Summary and Conclusion}

We designed, fabricated, and tested an experimental setup for in-situ time-lapse nondestructive investigation of water percolation in snow using the electrical properties of snow. Frequency heating close to the relaxation frequency of ice was applied to slowly increase the water content uniformly in the snow sample until liquid water started to percolate. By measuring the temperature and the applied power, the water content in the snow sample at each timestep was deduced. This new instrument allows to elucidating the starting point of water percolation based on measured electrical and morphological properties of the snow. The setup and the obtained results can be used to precisely forecast the run-off time of different density snowpacks and to investigate the mechanical properties, water movements, surface friction, adhesion, and liquid-water measurements, for wet snow and ice.

The experimental observation showed three different heating processes affecting the dielectric properties of snow for different densities: (1) dry snow heating process up to $0{ }^{\circ} \mathrm{C}$ indicating a temperature and snow structure dependency of the dielectric property of snow. At warmer temperature, slightly higher complex dielectric constant were measured having higher discrepancy for more dense snow; (2) wet snow heating at stagnating temperature of $0^{\circ} \mathrm{C}$ and the presence of uniformed distributed liquid water changes the dielectric properties and therefore reduces the impedance of the twophase material significantly until the starting point of water percolation; and (3) the start of water percolation is between 5-12 water volume fraction depending on the snow density. After this point the snow sample has an inhomogeneous mixture where liquid water treasures up at the bottom of the sample holder and is leaving bigger pores in the upper part leading to an increase of overall impedance of the snow sample.

Our results and conclusions indicate that there is a need for additional validation. Specially, it would be crucial to not only look at the density but also at the specific surface area of the snow at a given density which also affects the capillary forces and 
397 therefore the starting point of water percolation. Ideally, the entire snow sample will be

398 tomographically measured before the experiment to extract the morphological

399 parameters. The primarily micro-computer tomography (CT) result (Fig. 7) shows first

400 promising visualization of the preferred spots of liquid water in three-dimensional

401 space without destroying the snow structure. However, more detailed measurements

402 are needed to make stronger statements about preferential spots of water

403 accumulations inside the snow sample.

404

405 Acknowledgments:

406 The authors thank $\mathrm{H}$. Loewe and $\mathrm{B}$. Walter for the constructive reviews and the

407 modelling support. 


\section{References:}

Ali I. A.: "Effect of load on the heating efficiency and temperature uniformity in multimode cavity applicators", Journal of Microwave Power and Electromagnetic Energy, pp. 123-137, 2016. https://doi.org/10.1080/08327823.2016.1190170

Ambach W. and A. Denoth: "Studies on the dielectric properties of snow", Zeitschrift für Gletscherkunde und Glazialgeologie, pp. 113-123, 1972.

Ambach W. and A. Denoth: "On the dielectric constant of wet snow", Proceedings Snow Mechanics Symposium, IAHS-AISH Publication No 114, 1974.

Ambach W. and A. Denoth: "The dielectric behavior of snow: A study versus liquid water content", NTRS, 1980.

Auty R. P. and R. H. Cole: "Dielectric properties of ice and solid", Journal of Chemical Physics, pp. 1309-1314, 1952.

Bader H. and D. Kuroiwa: "The physics and mechanics of snow as a material", Cold Regions Science and Technology, Sect B., 1962.

Bartelt P. and M. Lehning: "A physical snowpack model for the swiss avalanche warning: Part i: numerical model", Cold Regions Science and Technology, pp. 123-145, 2002.

Boyne H. and D. Fisk: "Comparison of snow cover liquid water measurement techniques”, Water Resources Research, pp. 1833-1836, 1987.

Brun E.: "Investigation on wet-snow metamorphism in respect of liquid-water content", Annals of Glaciology, pp. 22-26, 1989.

Evans S.: "Dielectric properties of ice and snow - a review", Journal of Glaciology, pp. 773-792, 1965.

Camp P. R and D. R. LaBrecque: "Determination of the Water Content of Snow by Dielectric Measurements", Cold Regions Research \& Engineering Laboratory, pp. 1-39, 1992.

Colbeck S.: "A theory of water percolation in snow", Journal of Glaciology, pp. 369385, 1972.

Colbeck S.: "The capillary effects on water percolation in homogeneous snow", Journal of Glaciology, pp. 85-97, 1974.

Colbeck S.: "A theory for water flow through a layered snowpack", Water Resources Research, pp. 261-266, 1975. 
Colbeck S.: "The Difficulties of Measuring the Water Saturation and Porosity of Snow", Journal of Glaciology, pp. 189-201, 1978.

Colbeck S.: "Water flow through heterogeneous snow", Cold Regions Science Technology, pp. 37-45, 1979.

Colbeck S.: "An overview of Seasonal Snow Metamorphism, Rev. Geophys., 20, pp. 45-61, 1982.

Colbeck S.: "A review of sintering in seasonal snow", US Army Cold Regions Research and Engineering Laboratory Report, pp. 97-100, 1997.

Colbeck S. and G. Davidson: "Water percolation through homogeneous snow", IAHS publication, pp. 242-257, 1973.

Coléou C. and B. Lesaffre: "Irreducible water saturation in snow: experimental results in a cold laboratory", Annals of Glaciology, pp. 64-68, 1998

Conway H. and R. Benedict: "Infiltration of water flow into snow", Water Resource Research, pp. 641-650, 1994.

Denoth A.: "Snow dielectric measurements", Advanced Space Research, pp. 233-243, 1989.

Denoth A., A. Foglar, P. Wieland, C. Mätzler, H. Aebischer, M. Tiuri, and A. Sihvola: "The comparative study of instruments for measuring the liquid water content of snow", Journal of Applied Physics, pp. 2154-2160, 1984.

Fierz, C. and Föhn, P.: "Long-term observation of the water content of an Alpine snowpack", in: Proceedings International Snow Science Workshop 1994 Snowbird, Utah, USA, 117-131, 1994.

Fujita S., Matsuoka T., Ishida T., Matsuoka K. and S. Mae: 'A summary of the complex dielectric permittivity of ice in the megahertz range and its applications for radar sounding of polar ice sheets", Physics of Ice Core Records, Hokkaido University Press, 2000.

Hirashima H., S. Yamaguchi, and T. Katsushima: "A multi-dimensional water transport model to reproduce preferential flow in the snowpack", Cold Region Science Technology, pp. 80-90, 2014.

Illangasekare T. H., R. J. Jr. Walter, M. F. Meier, and W. T. Pfeffer: "Modeling of meltwater percolation in subfreezing snow", Water Resource Research, pp. 1001-1012, 1990.

Jordan R., M. Albert, and E. Brun: "Physical processes within the snow cover and their parametrization", in: Snow and climate: physical processes, surface energy 
exchange and modeling, edited by: Armstrong R. and E. Brun, Cambridge University Press, pp. 12-69, 2008.

Kaatze U.: "Complex permittivity of water as a function of frequency and temperature", Journal of Chemical and Engineering Data, pp. 371-374, 1989.

Koch F., M. Prasch, L. Schmid, J. Schweizer, and W. Mauser: "Measuring Snow Liquid Water Content with Low-Cost GPS Receivers", Sensors, pp. 20975-20999, 2014.

Lieb-Lappen R., E. Golden, and R. Obbard: "Metrics for interpreting the microstructure of sea ice using x-ray micro computed tomography", Cold Regions Science and Technology, pp. 24-35, 2017.

Marsh P. and M. Woo: "Meltwater movement in natural heterogeneous snow covers", Water Resources Research, pp. 1710-1716, 1985.

Marsh P.: "Grain growth in a wet Arctic snow cover", Cold Region Science Technology, pp. 23-31, 1987.

Marsh P.: "Flow fingers and ice columns in a cold snowcover", in: Proceedings Western Snow Conference, 18-20 April, 1988, Kalispell, Montana, 105-112, 1988.

Marshall H., H. Conway, and L. Rasmussen: "Snow densification during rain", Cold Region Science Technology, pp. 35-41, 1999.

Martinec J.: "Schneefeuchtigkeit mit dem Denoth-Gerät im Vergleich mit dem Handtest, Messungen 11989, 1990 (Snow wetness with the Denoth-meter in comparison to the hand test, measurements 1989, 1990)", internal report 677 (unpublished), WSL Institute for Snow and Avalanche Research SLF, Davos, 1999b.

Mellor M.: "Engineering properties of snow", Journal of Glaciology, pp. 15-66, 1977.

Löwe H., J. K. Spiegel, M. Schneebeli: "Interfacial and structural relaxations of snow under isothermal conditions, Journal of Glaciology, pp. 499-510, 2011.

Lupi S.: "Fundamentals of Electroheating", Springer, ISBN 978-3-319-46015-4, 2017.

Perla R.: "Real permittivity of snow at $1 \mathrm{MHz}$ and $0^{\circ} \mathrm{C}$ ", Cold Regions Science and Technology, pp. 215-219, 1991.

Polder D. and J. H. van Santeen: "The effective permeability of mixtures of solids", Physica, pp. 257-271, 1946. 
Raymond C. and K. Tusima: "Grain coarsening of water saturated snow", Journal of Glaciology, pp. 83-105, 1979.

Reiwegger I., J. Gaume, and J. Schweizer: "A new mixed-mode failure criterion for weak snowpack layers", Geophysical Research Letters, pp. 1427-1432, 2015.

Riche F. and M. Schneebeli: "Thermal conductivity of snow measured by three independent methods and anisotropy considerations", The Cryosphere, pp. 217-227, 2013.

Schleef S., M. Jaggi, H. Löwe, and M. Schneebeli: "An improved machine to produce nature-identical snow in the laboratory", Journal of Glaciology, pp. 94-102, 2014.

Sihvola A., E. Nyfors, and M. Tiuri: "Mixing formulae and experimental results for the dielectric constant of snow", Journal of Glaciology, pp. 163-170, 1985.

Smith J. L.: "Hydrology of warm snowpacks and their effects upon water delivery some new concepts", Advanced Concepts and Techniques in the Study of Snow and Ice Resources", pp. 76-89, 1974.

Sweeny B. D. and S. Colbeck: "Measurements of the Dielectric Properties of Wet Snow Using a Microwave Technique", Cold Regions Science and Technology, Research Report 325, 1974.

Techel F., C. Pielmeier, and M. Schneebeli: "Microstructural resistance of snow following first wetting", Cold Region Science Technology, 65, pp. 382-391, 2001.

Tiuri M., A. Sihvola, E. Nyfors, and M. Hallikaiken: "The complex dielectric constant of snow at microwave frequencies", IEEE Journal of Oceanic Engineering, pp. 377-382, 1984.

Tseng P., T. Illangesakare, and M. Meier: "Modeling of snow melting and uniform wetting from migration in a layered subfreezing snowpack", Water Resource Research, pp. 2363-2376, 1994.

Wever N., C. Fierz, C. Mitterer, H. Hirashima, and M. Lehning: "Solving Richards equation for snow improves snowpack meltwater runoff estimations in detailed multi-layer snowpack model”, The Cryosphere, pp. 257-274, 2014.

Yamaguchi S., T. Katsushima, A. Sato, and T. Kumakura: "Water retention curve of snow with different grain sizes", Cold Regions Science and Technology, pp. 8793, 2010 . 
541 Table 1: Density of the snow samples and the corresponding voltage $U_{\mathrm{RMS}}$, current

$542 I_{\mathrm{RMS}}$, and phase shift $\varphi_{\mathrm{RMS}}$ at the start of the experiment (init), reaching $0{ }^{\circ} \mathrm{C}$ (dry-wet)

543 and the point where the power is maximum (peak).

\begin{tabular}{c|ccc|ccc|cccc}
$\begin{array}{c}\text { Density } \\
\left(\mathrm{kg} \mathrm{m}^{-3}\right)\end{array}$ & \multicolumn{3}{|c|}{$\begin{array}{c}U_{\text {RMS }} \\
(\mathrm{V})\end{array}$} & \multicolumn{3}{c|}{$\begin{array}{c}\text { IRMS } \\
(\mathrm{mA})\end{array}$} & \multicolumn{3}{c}{$\begin{array}{c}\varphi_{\mathrm{RMS}} \\
\left({ }^{\circ}\right)\end{array}$} \\
\hline & init & dry-wet & peak & init & dry-wet & peak & init & dry-wet & peak \\
\hline 427 & 325.5 & 325.6 & 326.9 & 0.81 & 0.82 & 1.21 & 57.4 & 57.3 & 48.7 \\
438 & 332.6 & 327.2 & 328.0 & 0.90 & 0.90 & 1.66 & 55.9 & 55.7 & 41.4 \\
465 & 328.0 & 328.3 & 328.1 & 1.14 & 1.16 & 1.83 & 52.2 & 52.2 & 40.6 \\
465 & 329.4 & 330.1 & 329.9 & 1.10 & 1.13 & 1.81 & 52.4 & 52.1 & 40.7 \\
539 & 339.1 & 329.3 & 327.8 & 1.23 & 1.29 & 2.58 & 52.8 & 51.0 & 35.2 \\
612 & 331.3 & 332.0 & 327.0 & 1.55 & 1.65 & 3.76 & 49.5 & 48.8 & 31.5 \\
917 & 336.5 & 327.9 & 313.8 & 2.73 & 3.41 & 4.27 & 46.9 & 34.5 & 22.4
\end{tabular}


545 Table 2: Density of the snow samples and the corresponding impedance $U_{\text {RMs }}$ and 546 power $P_{\mathrm{RMS}}$ at the start of the experiment (init), reaching $0{ }^{\circ} \mathrm{C}$ (dry-wet) and the point 547 where the power is maximum (peak).

\begin{tabular}{c|ccc|ccc}
$\begin{array}{c}\text { Density } \\
\left(\mathrm{kg} \mathrm{m}^{-3}\right)\end{array}$ & \multicolumn{3}{|c|}{$\begin{array}{c}R_{\mathrm{RMS}} \\
(\mathrm{k} \Omega)\end{array}$} & \multicolumn{3}{|c}{$\begin{array}{c}P_{\mathrm{RMS}} \\
(\mathrm{W})\end{array}$} \\
\hline & init & dry-wet & peak & init & dry-wet & peak \\
\hline 427 & 403.4 & 396.9 & 269.4 & 0.14 & 0.14 & 0.26 \\
438 & 368.4 & 362.0 & 197.5 & 0.17 & 0.17 & 0.41 \\
465 & 287.8 & 282.4 & 179.2 & 0.23 & 0.23 & 0.46 \\
465 & 300.4 & 291.1 & 182.3 & 0.22 & 0.23 & 0.45 \\
539 & 275.5 & 254.8 & 127.3 & 0.25 & 0.27 & 0.69 \\
612 & 213.4 & 213.4 & 87.3 & 0.33 & 0.36 & 1.04 \\
917 & 123.1 & 123.1 & 73.5 & 0.63 & 0.92 & 1.24
\end{tabular}

548 
https://doi.org/10.5194/tc-2020-56

Preprint. Discussion started: 3 May 2020

(c) Author(s) 2020. CC BY 4.0 License.

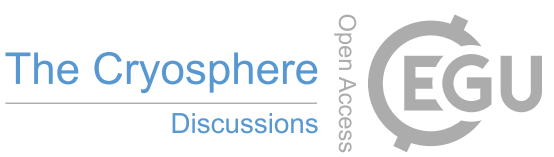

549 Table 3: Density of the snow samples and the corresponding heating time and the

550 water mass and volume fraction where water starts to percolate.

\begin{tabular}{cccc}
$\begin{array}{c}\text { Density } \\
\left(\mathrm{kg} \mathrm{m}^{-3}\right)\end{array}$ & $\begin{array}{c}\text { Heating time } \\
(\mathrm{min})\end{array}$ & $\begin{array}{c}\text { Water mass fraction } \\
(\%)\end{array}$ & $\begin{array}{c}\text { Water volume fraction } \\
(\%)\end{array}$ \\
\hline 427 & 94.5 & 4.1 & 3.3 \\
438 & 81.1 & 6.4 & 5.2 \\
465 & 51.2 & 4.3 & 4.1 \\
465 & 55.2 & 4.6 & 4.2 \\
539 & 58.2 & 5.8 & 7.3 \\
612 & 54.5 & 7.5 & 12.9 \\
917 & 8.79 & 0.3 & 0
\end{tabular}


553 Figure 1: The experimental setup consisting of three functional blocks (1) low voltage

554 circuit to generate the sinusoidal signal and amplify the energy output, (2) high voltage

555 circuit to transform the low primary voltage to a high secondary voltage, and (3) design

556 of the sample holder between the high voltage capacitor plates.

557 Figure 2: (Top) Illustration of the snow heating device. The setup includes a function 558 generator, an audio amplifier and a plastic box with all the high voltage parts. The lid 559 of the box is secured by a safety switch. (Bottom) An illustration of the inner part of the 560 box is shown. It illustrates the high voltage parts with the $60 \mathrm{~mm}$ capacitor.

561 Additionally, the CT sample holder with the $34 \mathrm{~mm}$ capacitor is shown.

562 Figure 3: Typical measured temperature $T(\mathrm{t})$, current $I_{\mathrm{RMS}}(\mathrm{t})$, voltage $U_{\mathrm{RMS}}(\mathrm{t})$, and 563 phase shift $\varphi(t)$ profile of a heating process for snow density of (a) $438 \mathrm{~kg} \mathrm{~m}^{-3}$, (b) 539 $564 \mathrm{~kg} \mathrm{~m}^{-3}$, (c) $612 \mathrm{~kg} \mathrm{~m}^{-3}$, and (d) $917 \mathrm{~kg} \mathrm{~m}^{-3}$.

565 Figure 4: Typical measured temperature $T(\mathrm{t})$, impedance $R_{\mathrm{RMS}}(\mathrm{t})$ and power $P_{\mathrm{RMS}}(\mathrm{t})$, 566 profile of a heating process for snow density of (a) $438 \mathrm{~kg} \mathrm{~m}^{-3}$, (b) $539 \mathrm{~kg} \mathrm{~m}^{-3}$, (c) 612 $567 \mathrm{~kg} \mathrm{~m}^{-3}$, and (d) $917 \mathrm{~kg} \mathrm{~m}^{-3}$.

568 Figure 5: Heating efficiency and the complex dielectric constant of dry snow at $T=0$

$569{ }^{\circ} \mathrm{C}$ for various snow sample.

570 Figure 6: The temporal evolution of the liquid water mass and volume fraction based 571 on the measured power for snow density of (a) $438 \mathrm{~kg} \mathrm{~m}^{-3}$, (b) $539 \mathrm{~kg} \mathrm{~m}^{-3}$, (c) $612 \mathrm{~kg}$ $572 \mathrm{~m}^{-3}$, and (d) $917 \mathrm{~kg} \mathrm{~m}^{-3}$.

573 Figure 7: 3D micro-computer tomography (CT) picture to visualize the water content 574 in snow after water percolation. The scanned image has a volume of $200 \times 200 \times 20$ 575 voxels $(3.6 \mathrm{~mm} \times 3.6 \mathrm{~mm} \times 0.36 \mathrm{~mm})$. Blue indicates the ice structure and orange shows 576 the water part.

577 Figure 8: Photography under the microscope to illustrate the liquid water content in 578 the wet snow sample: (left) snow structure of snow before the experimental run, (right) 579 the same snow sample after 2 hours with an estimated liquid-water content of $12 \mathrm{wt} \%$. 
580 Figure 9: Dividing the heating process in three different processes: (1) dry snow

581 heating process up to $0{ }^{\circ} \mathrm{C}$ indicating a temperature and snow structure dependency

582 on the measured values; (2) wet snow heating at stagnating temperature of $0^{\circ} \mathrm{C}$ and

583 the presence of uniformed distributed liquid water changes the dielectric properties of

584 the snow sample; and (3) starting point of water percolation in the snow sample

585 introducing an inhomogeneous mixture where liquid water treasures up at the bottom

586 of the sample holder and is leaving bigger pores in the upper part.

587 Figure 10: Visualization of water percolation after an experimental run. The sample 588 holder was aligned vertically between the capacitor plates. Water percolated in the 589 upper part of the sample and accumulated at the bottom of the sample holder leading

590 to an inhomogeneous mixture of the sample affecting the heating process of the 591 sample. 
https://doi.org/10.5194/tc-2020-56

Preprint. Discussion started: 3 May 2020

(c) Author(s) 2020. CC BY 4.0 License.

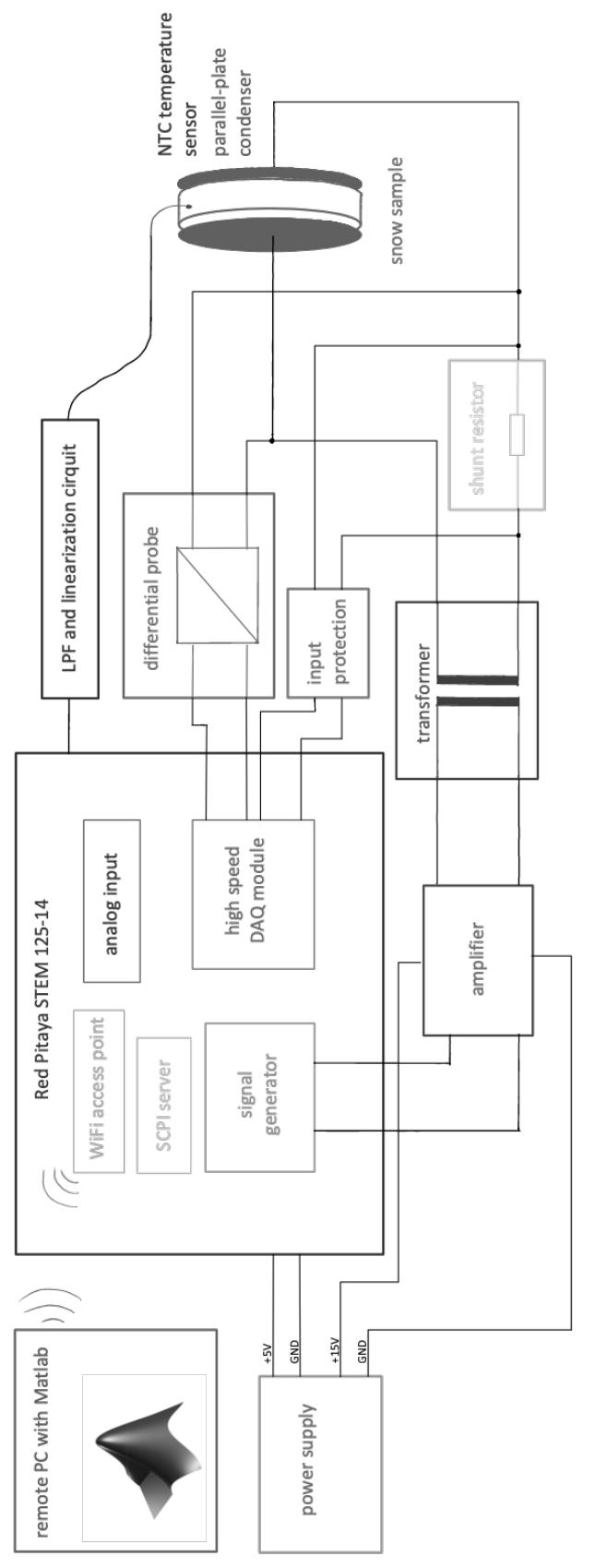

Figure 1 
https://doi.org/10.5194/tc-2020-56

Preprint. Discussion started: 3 May 2020

(c) Author(s) 2020. CC BY 4.0 License.

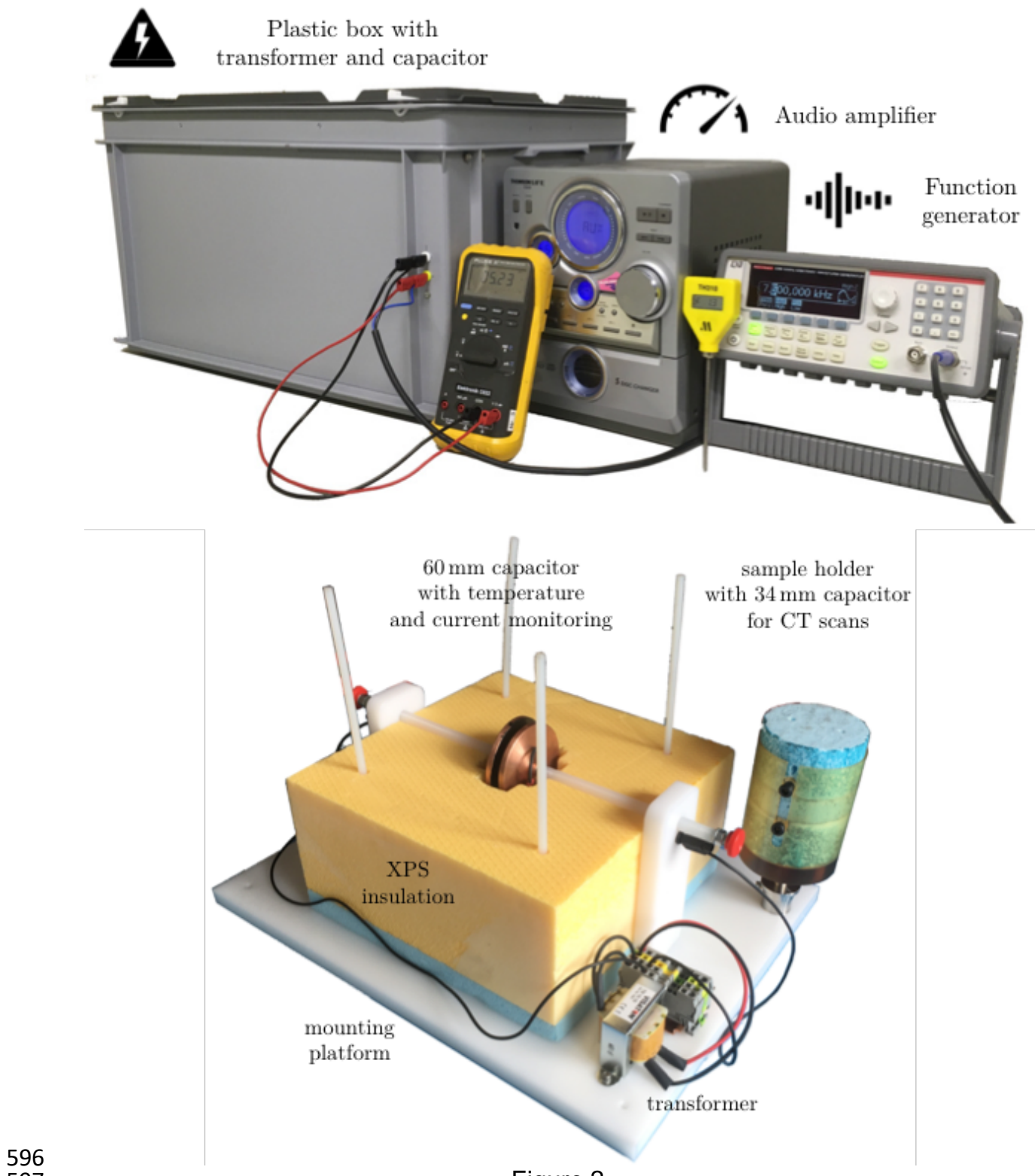

Figure 2 
https://doi.org/10.5194/tc-2020-56

Preprint. Discussion started: 3 May 2020

(c) Author(s) 2020. CC BY 4.0 License.

598

599

600

601

602

603 a)
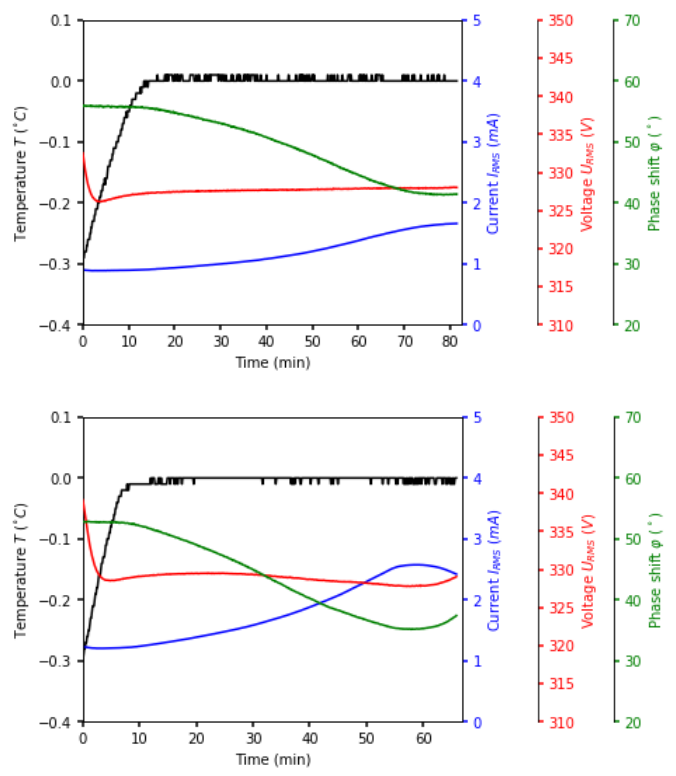

b)

c)
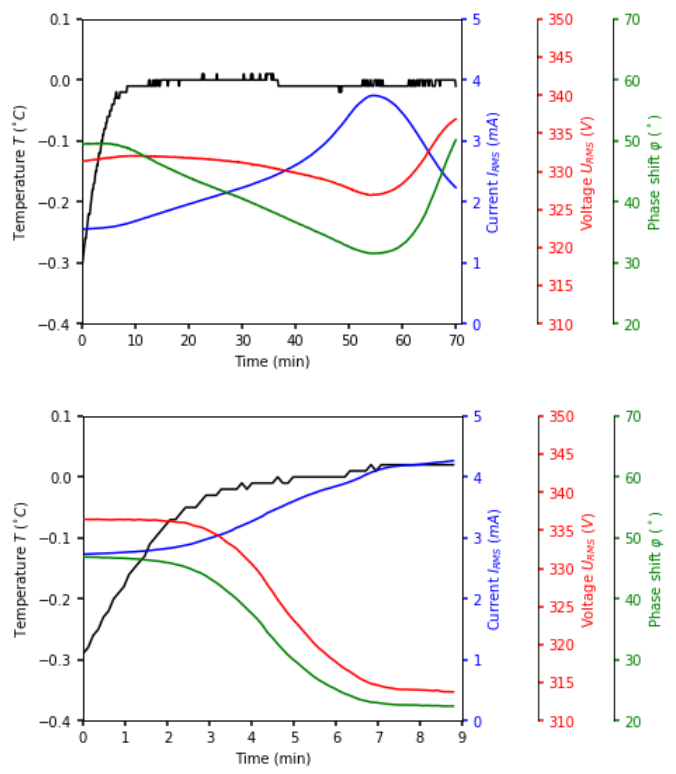

Figure 3 
https://doi.org/10.5194/tc-2020-56

Preprint. Discussion started: 3 May 2020

(c) Author(s) 2020. CC BY 4.0 License.

604

605

606

607

608

609 a)

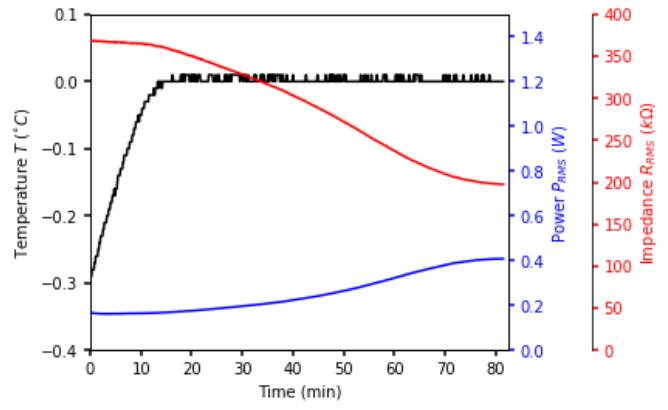

b)
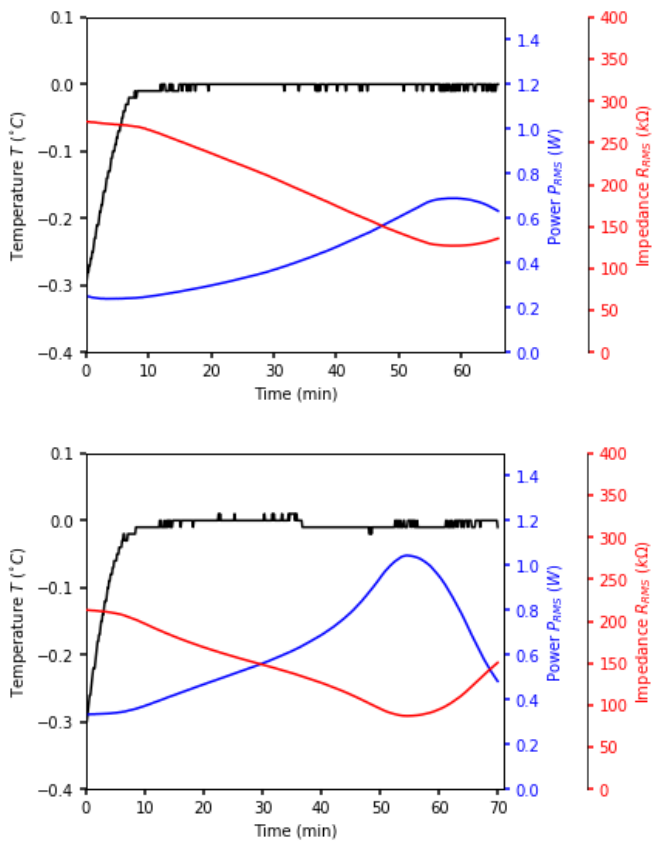

c)

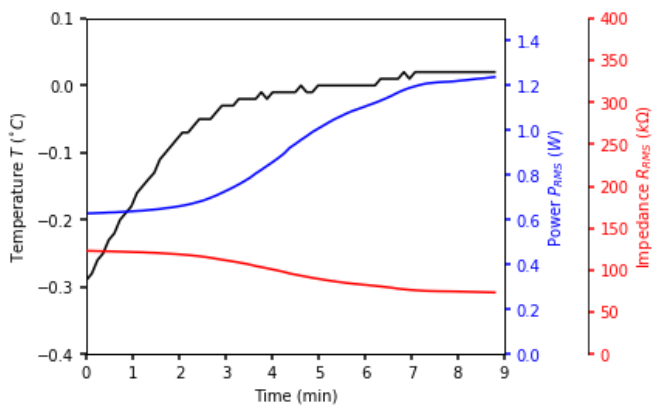

Figure 4 
https://doi.org/10.5194/tc-2020-56

Preprint. Discussion started: 3 May 2020

(c) Author(s) 2020. CC BY 4.0 License.

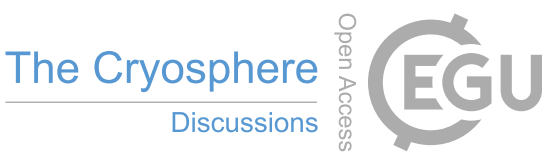

(c) ${ }_{\mathrm{BY}}$

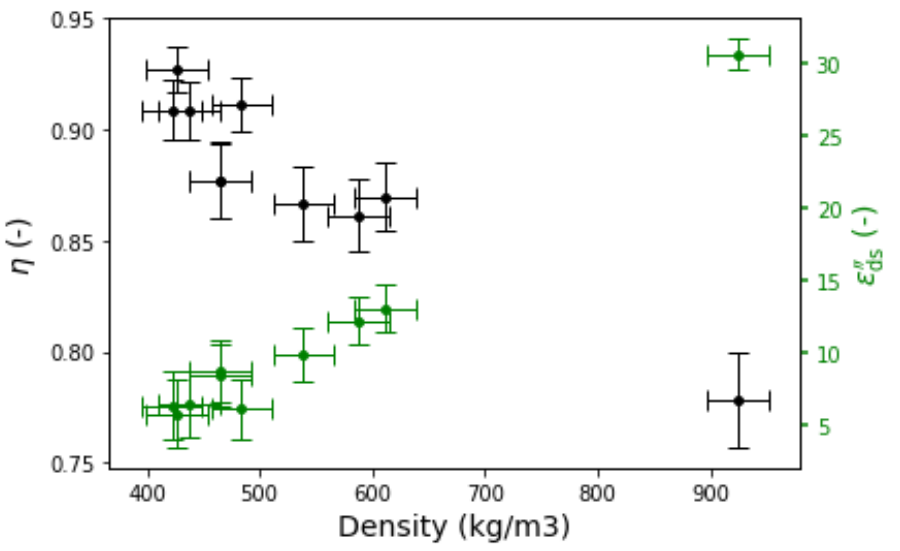

610

611

612

Figure 5 
https://doi.org/10.5194/tc-2020-56

Preprint. Discussion started: 3 May 2020

(c) Author(s) 2020. CC BY 4.0 License.

613

614

615 a)
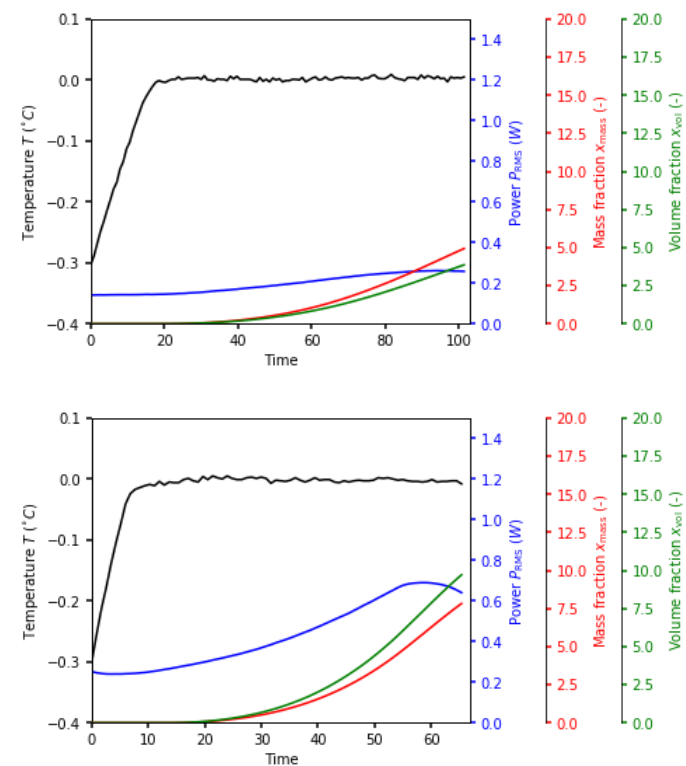

b)

c)
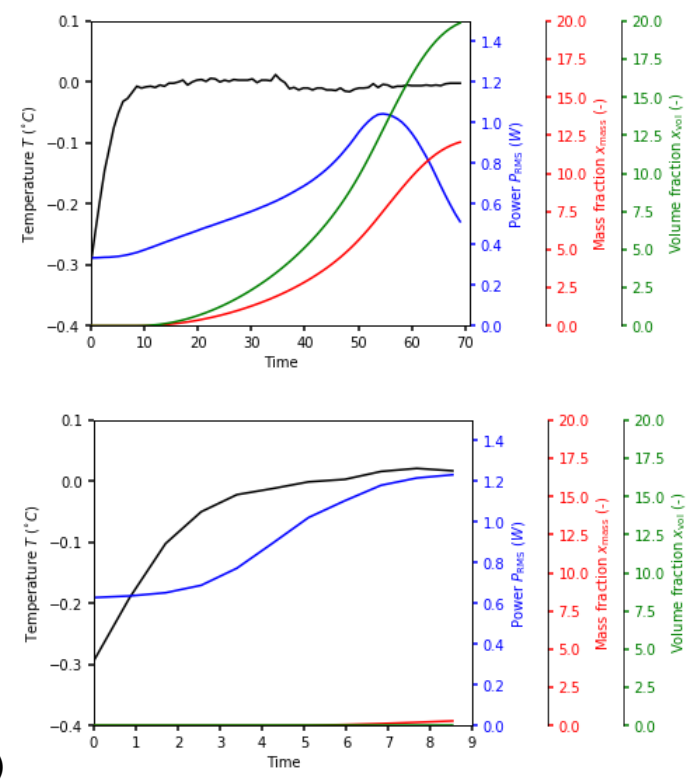


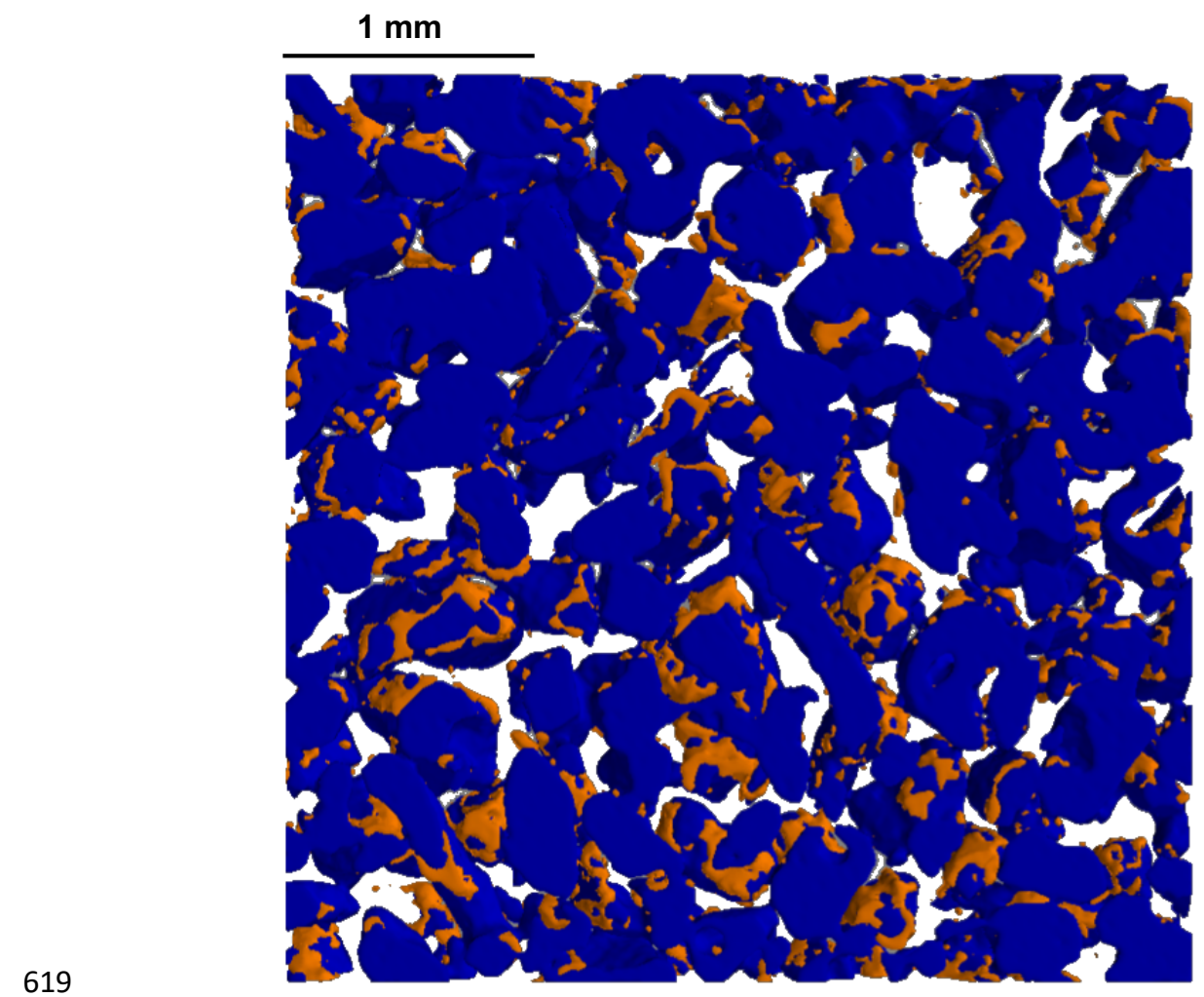

Figure 7

622 
https://doi.org/10.5194/tc-2020-56

Preprint. Discussion started: 3 May 2020

(c) Author(s) 2020. CC BY 4.0 License.

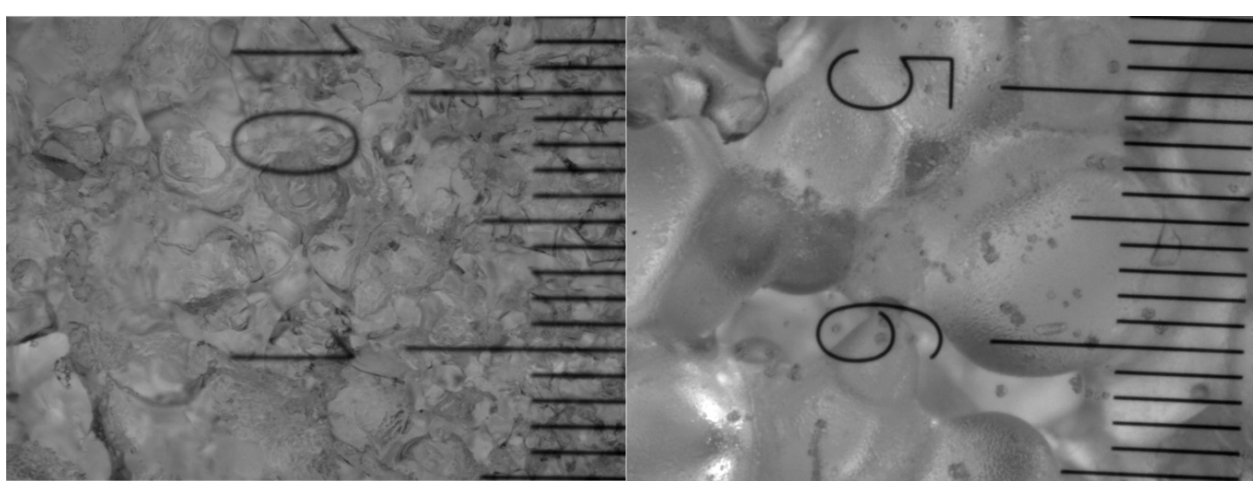

Figure 8 
https://doi.org/10.5194/tc-2020-56

Preprint. Discussion started: 3 May 2020

(C) Author(s) 2020. CC BY 4.0 License.

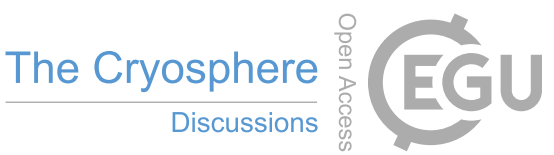

(c) (i)

628

629

630

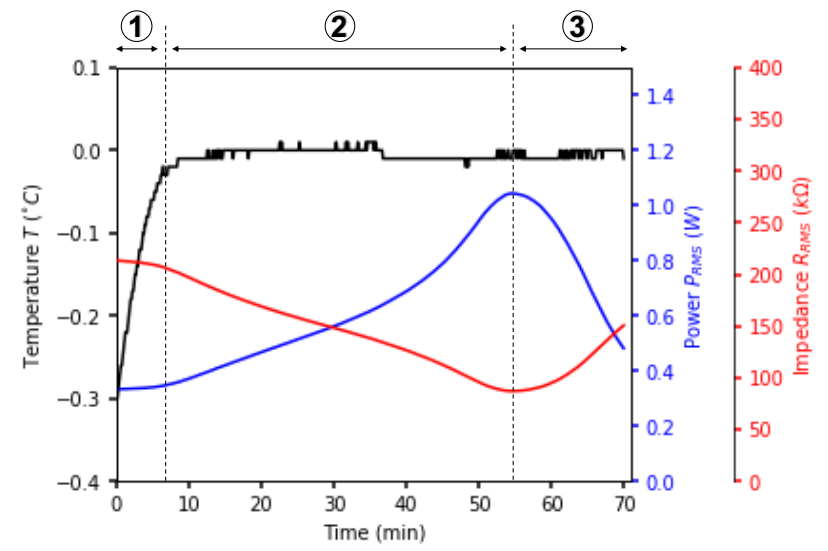

Figure 9 
https://doi.org/10.5194/tc-2020-56

Preprint. Discussion started: 3 May 2020

(C) Author(s) 2020. CC BY 4.0 License.

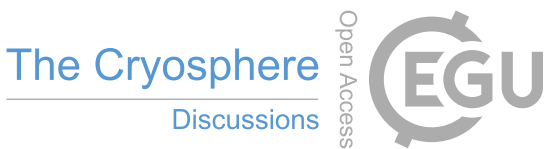
(c) (1)

631

632

633

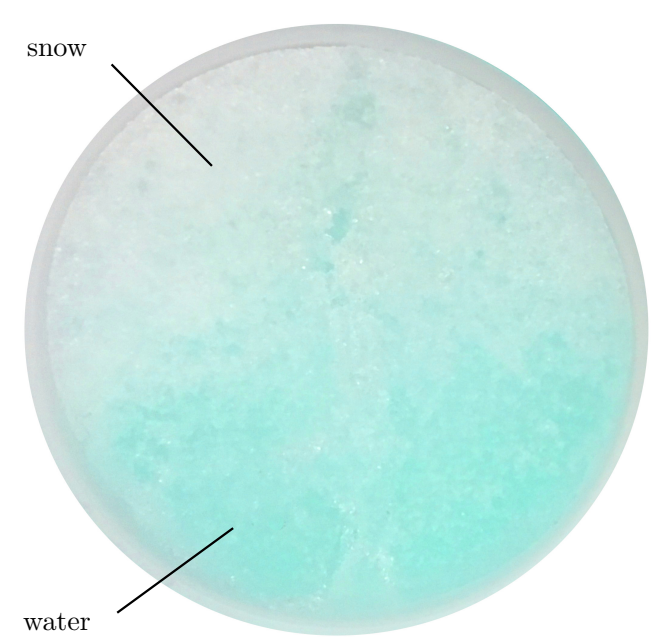

Figure 10 